\title{
Kernos
}

Revue internationale et pluridisciplinaire de religion grecque antique

$25 \mid 2012$

Varia

\section{Charles DOYEN, Poséidon souverain. Contribution à l'histoire religieuse de la Grèce mycénienne et archaïque}

Joannis Mylonopoulos

\section{(2) OpenEdition}

\section{Journals}

Electronic version

URL: http://journals.openedition.org/kernos/2052

DOI: 10.4000/kernos.2052

ISSN: 2034-7871

\section{Publisher}

Centre international d'étude de la religion grecque antique

\section{Printed version}

Date of publication: 26 October 2012

Number of pages: $336-340$

ISSN: 0776-3824

\section{Electronic reference}

Joannis Mylonopoulos, « Charles Doyen, Poséidon souverain. Contribution à l'histoire religieuse de la Grèce mycénienne et archaïque », Kernos [Online], 25 | 2012, Online since 01 October 2012, connection on 21 September 2020. URL : http://journals.openedition.org/kernos/2052 ; DOI : https://doi.org/ 10.4000/kernos.2052

This text was automatically generated on 21 September 2020

Kernos 


\title{
Charles DOYEN, Poséidon souverain. Contribution à l'histoire religieuse de la Grèce mycénienne et archaïque
}

\author{
Joannis Mylonopoulos
}

\section{REFERENCES}

Charles DOYEN, Poséidon souverain. Contribution à l'histoire religieuse de la Grèce mycénienne et archaïque, Bruxelles, Académie Royale de Belgique, 2011.1 vol. $16 \times 24 \mathrm{~cm}, 391 \mathrm{p}$. (Mémoire de la Classe des Lettres in $-8^{\circ}, 3^{\mathrm{e}}$ série, tome $55, \mathrm{n}^{\circ} 2072$ ). ISBN :

978-2-8031-0279-2.

1 The present study is an up-to-date version of a $\mathrm{PhD}$ submitted to the Catholic University of Leuven in 2009. As the A. states in the introduction (p. 17-30), he originally intended to work on the influences of the "héritage religieux proprement hellénique et de mythes orientaux repensés" on Greek religion and the thought of the Archaic period in general. In the process of trimming down this rather ambitious project, he soon decided that Poseidon was an interesting case study, seeing that the god appears to have gone through significant changes - a "decline" - from being perhaps the most important deity in the Mycenaean pantheon to an inferior god in the Archaic period. As an all-encompassing study of the Greek Poseidon was too vast, D. chose instead to focus on the paternal and kingly aspects of the god, as is evident from the final title he gave his monograph.

2 D.'s approach and methods are explicitly philological. His study is based on Archaic and fifth-century Classical literary sources from the Greek world, Mycenaean Linear B tablets (mainly from Pylos), and Near Eastern mythological texts. Its objective is to reconstruct an evolution of Greek religion from a "society of Poseidon" to a "society of 
Zeus". The book is thus organized chronologically in three sections: the first deals with Poseidon in the Archaic period ("Poséidon archaïque," p. 31-117); the second with the Mycenaean cult of the god ("Poséidon mycénien," p. 119-263); and the third compares oriental to Mycenaean/Greek panthea ("Panthéons grecs, panthéons orientaux," p. 265-332). Each section is subdivided into two chapters. The work concludes with bibliographical references (p. 341-362) and detailed indices (p. 363-382). Chapter One ("Athéna et Poséidon sur l'acropole athénienne," p. 33-75) focuses on two Athenian myths associated with the Acropolis: the dispute between Athena and Poseidon over Attica, and the birth of Erichthonios. The A. centres his attention on the role of Poseidon in the birth of mythical horses, such as Areion or Pegasos, and presupposes that the myth of Erichthonios' birth likewise evolved from one about the parenting of a child in the form of a horse. Following the out-dated hypothesis proposed by Fritz Schachermeyr in his 1950 monograph on Poseidon, namely that an otherwise unattested chthonian Poseidon Hippos (a god in the form of a horse) was the predecessor of the historical Poseidon Hippios, D. suggests that this allegedly Mycenaean chthonian horse-god was, in fact, the spouse of a goddess with whom Poseidon sired several of the wondrous horses of Greek mythology. His brief discussions of the local traditions surrounding the birth of $\operatorname{Ar}(\mathrm{e})$ ion (Arcadia and Boeotia), Skyphios (Thessaly and Attica), as well as Pegasos (Korinth) reveal that D. is not really taking into consideration the chronological frame of literary sources as he uses and tries to decode them. Instead, he uses sources as chronologically disparate as Hesiod and Tzetzes, as if they enjoyed exactly the same reliability. Here D. also reveals his rather superficial knowledge of archaeological and iconographic material. In the sub-chapter dedicated to Pegasos, for example, he overemphasizes the significance of three objects - a Cycladic relief amphora and two gems, none of which dates after the second quarter of the $6^{\text {th }}$ cent. - that depict Medusa with the body of a horse. These objects, in fact, belong to a time when artists had not yet 'fixed' the iconographical traits of every mythological figure, and thus too much should not be made of three occurrences of a specific type of Medusa-image that was eventually to prove unsuccessful. More importantly, D. refers to two cups (early $6^{\text {th }}$ cent.) and a volute crater ( $4^{\text {th }}$ cent.) that allegedly depict Medusa with a horse-head, failing to recognize that the scenes actually depict the moment of Pegasos' birth. It is Pegasos' head that one sees emerging from the neck of the decapitated Medusa and by no means a horseheaded Medusa. ${ }^{1}$ As for Pegasos and Chrysaor, the A. chooses to depend once again on scholarship from the first half of the $20^{\text {th }}$ century that associates the two figures with a Zeus "de Carie et de Lycie". While searching for Poseidon, the father of horses, in Attica, the A. associates mythological figures, such as Halirrhothios, Hippothoon, Alope, Kerkyon, Kychreus, and Kekrops, with specific locations, such as Eleusis, Salamis, Phaleron, Skiron, Hippios Kolonos, and even Thebes and Mantineia. In the centre of his imaginative but highly speculative reconstruction lies the birth of a child in the form of a horse, as well as a Poseidonian connection among all the aforementioned places and the Acropolis of Athens.

D. continuously brings together chronologically disparate sources and uses material evidence regardless of its date. For example, he uses the Roman temple of Artemis Propylaia and Poseidon Pater in Eleusis to support his argument that Hippothoon originally had the form of a horse and that there were myths from Eleusis that identified Poseidon as the father (Pater) of a horse. Given this gist, it seems inevitable that the A. suggests that Poseidon rather than Hephaistos was the genitor in the 
original version of Erichthonios' birth. He claims, in fact, that Gaia was not simply Mother Earth, but more concretely the Acropolis, while the names of the Kekropids indicate a close association with water and thus with Demeter. ${ }^{2}$ Thus Aglauros could initially have been the "première mère d'Érichthonios" as the "entité maternelle locale." D. further speculates that in this original, albeit completely unattested version of the story of Erichthonios' birth, the divine child assumed the form of a horse. According to D.'s hypothesis, later versions of the myth of the quarrel between Poseidon and Athena over Attica, which refer to a horse as the god's gift to the Athenians, do in fact hark back to the original version of Erichthonios' birth. D. dedicates the rest of Chapter One to a hypothetical reconstruction of the gradual substitution of Aglauros and Poseidon with Gaia/Athena and Hephaistos/Kekrops as the parents or adoptive parents of Erichthonios. Finally, he explains the transformation of Erichthonios from a horse- to a snake-human figure in the context of a political effort bent on emphasizing the notion of Athenian autochthony.

Based on literary sources (mainly Homer, Hesiod, Pindar), Chapter Two ("Zeus et Poséidon dans la littérature grecque," p. 77-117) attempts to understand the role of Zeus as compared to Poseidon in the Greek pantheon. Here D. analyzes three cardinal

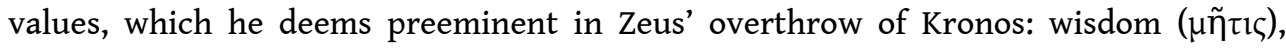

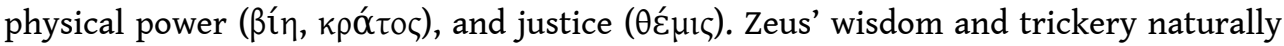
link him to Athena, but also to Homeric heroes, such as Odysseus and Hector, who are likewise compared in this aspect to Zeus. Within the context of wisdom and trickery, D. identifies and discusses Kronos, Prometheus, and the never-born son of Metis as adversaries of Zeus. With respect to Zeus' physical power, D. discusses briefly the ways in which ancient authors, especially Hesiod, constructed the notion of this power, based not only on the god's physical dominance, but also on his powerful allies as well as his thunderbolt. Epithets such as those used by Pindar to characterize Zeus are often directly associated with the god's power. With regard to physical power, Achilles is obviously Zeus' equivalent among Homeric heroes. Power and trickery were necessary for Kronos' overthrow, but it was with his sense of justice that Zeus created what the A. calls the "society of Zeus". Relying on the Hesiodic Theogony, the A. addresses how Zeus' connection with Themis and their parenting of the Horai and the Moirai both contributed to and were the result of the god's justice. Basing his argument almost entirely on the Iliad - with occasional references to the Theogony - D. goes on to discuss the ambivalent relationship between the two divine brothers while emphasizing their radical differences as well as Poseidon's inferiority to Zeus in the Homeric poem. Towards the end of this chapter, D. addresses possible interconnections between Kronos and Poseidon as wells as between Poseidon and the Cyclops. The A. does manage to demonstrate the depth of his knowledge especially of the Homeric and Hesiodic poems, but one cannot help but ask why we need yet another reminder of Poseidon's inferiority to Zeus in the works of Homer and Hesiod. Although the A. does not explicitly express this, the impression one gets is that he elevates literary imagination to the level of hard evidence in matters of cultic significance in a way that reminds the reader of a long out-dated approach to studying ancient religion that relied exclusively on the descriptive lens of ancient literature. Methodologically, the A. chose not even to address the ambivalent and highly problematic interrelationship between myth, literature, cult, and ritual. This becomes more of a problem in the next chapter where he focuses on Mycenaean texts of a completely different nature. 
Chapter Three ("Poséidon propriétaire terrien. Cadastres et impôts fonciers à Pylos," p. 121-201) is the longest in the book and discusses in great detail the evidence of the Linear B tablets from Pylos. D. does not confine himself to general remarks, but analyses the evidence from both a purely linguistic and a broader social, economic, and religious perspective. D. first discusses the dossier of the Es series from Pylos. He scrutinizes the structure of the texts that refer inter alia to tenants of Pylian land and their contributions to Poseidon. The A. often interrupts the flow of his text with analyses of rather secondary issues, which do not contribute to the main aims of the monograph. For example, he suggests that the term 34-ke-te-re can be read as $\lambda u \kappa \tau \tilde{\eta} \rho \varepsilon \varsigma$ and that this could have been a collegium of officials with sacral duties, comparable to the much later $\delta \alpha \delta o$ ṽ $x$. With respect to the term di-wi-je-u, the A. suggests that it is a person's name rather than a term describing a function associated with a priestly official for Zeus. After a rigorous discussion of the dossier of the sa-ra-pe-da series, D. proposes that the term $s a-r a-p e-d a$ is probably a place-name and refers to royal land from which tributes were offered to Poseidon rather than sacred land belonging to Poseidon. In the second half of the chapter, D. discusses terms, such as e-ke-ra ${ }_{2}-w_{0}$ (a high-ranking landowner with connections to the cult of Poseidon), ko-to-na ki-ti-me-na, ke-ke-me-na ko-to-na, ka-ma and e-re-mi-jo (terms related to land property), as well as institutions and officials, such as the wanax, the three telestai, the lawagetas, or the damos. D. argues against the hypothesis that wo-ro-ki-jo-ne-jo should be seen as some kind of religious association and suggests that it is an adjective that defines the land that belonged to a person named Wroikiôn. Towards the end of the chapter, he includes a useful discussion of the priestess Eritha and the key-bearer (perhaps associated with the much later term $\kappa \lambda \varepsilon 1 \delta \circ \tilde{x} \chi \circ)$ Karpathia.

7 The first part of Chapter Four ("Fêtes et sanctuaires au royaume de Pylos," p. 203-263) attempts to reconstruct Mycenaean festivals primarily on the basis of the series Fr of the Linear B tablets from Pylos. After discussing the linguistic evidence, D. rejects the possibility that terms, such as Wanassa or Dipsia refer to locations. Instead, they as well as the terms Xenia, Pakijania, and Lekhestroterion most probably designated festivals in which in addition to Poseidon, various other deities and the wanax were honoured with offerings of perfumed oil. The longest section of the chapter, however, is dedicated to a detailed analysis of the famous Linear B text Tn 316 with its list of divinities and sanctuaries in the Pylian kingdom. According to D., the term po-ro-wi-to, which functions as the title of Tn 316, cannot be seen as the name of a month or locality. The A. proposes instead that it describes a specific ritual act, most probably a preliminary offering, sort of an $\dot{\alpha} \pi \alpha \rho \chi \eta ்$, for an unknown festival. If this is true, then Tn 316 is not dealing with an exceptional moment, as has been often suggested, but rather with a part of regular religious acts. Nevertheless, the nature of the offerings - several gold vases of various types - suggests that the objects could not have been part of a preliminary ritual. D. then discusses the divinities mentioned in the tablet according to their place (localities or sanctuaries) of veneration as listed in the text: a) Potnia, ma$n a-s a$, Posidaheia, Trisheros, do-po-ta in pa-ki-ja-na, b) Poseidon, qo-wi-ja-na, and ko-mawe-te-ja in the Posidahion (the sanctuary of Poseidon), c) pe-re-82, Iphimedeia, Diwya, and Hermes, honoured with the exception of Hermes in their own sanctuaries, d) Zeus, Hera, and di-ri-mi-jo in the Diwyon (the sanctuary of Zeus). Here D. rightfully stresses the absence of Posidaheia and Diwya from the sanctuaries of their respective divine husbands. 
Chapter Five ("Le Poséidon hellénique. Questions de souveraineté divine," p. 267-299) opens with one of the main premises of the book: Poseidon was the main deity of the Mycenaean pantheon - hence D.'s pre-assumption of a "Poseidonian society" - while Poseidon's displacement in later periods led to the birth of a "society of Zeus." The A. suggests that in the Pylian sacred district of pa-ki-ja-na, Poseidon and not Potnia was the main divinity. Furthermore, he claims that all sanctuaries mentioned in Tn 316 should be localized within pa-ki-ja-na, a suggestion supported by the structure of the text. The A. is right to emphasize the close connections among Poseidon and his cult, the land/earth of Pylos and its territories, the members of the Pylian elite, and especially the wanax. In the second half of the chapter, D. returns to what he calls the "Poséidon archaïque" and summarizes the theses he expressed in Chapter One (the evolution of Zeus to the king of gods and men, Poseidon's decline to a god inferior to Zeus, the transformation of Athenian myths so as to cloud former Poseidonian preeminence). The last sub-chapter on Poseidon Hippios and Taurios announces the focus of the book's final chapter. The A. concludes that the god's connections to the horse and the bull reflect two distinct traditions: an Indo-European one that considered the horse a royal animal, and a Near Eastern, which regarded the bull as the symbol or even incarnation of gods and sovereigns. Considering the bull and its semantics, one wonders why D. does not address possible Minoan influences, as Minoan and especially Knossian imagery assigned the bull an obvious prominence among divine and royal symbols.

9 In the first half of Chapter Six ("Un Poséidon oriental? Modèles de souveraineté divine," p. 301-332) after a brief discussion of the Hittite-Hurrian Kumarbi cycle and the Old Babylonian Enûma Eliš, D. focuses on Ugaritic myths of divine sovereignty and royalty. The Hittite-Hurrian and Old Babylonian mythological cycles as well as the Hesiodic work present a patrilineal, albeit brutal succession of gods. In D.'s view the coexistence and collaboration of $\mathrm{Ba}$ 'al and his father $\mathrm{El}$ in Ugaritic mythology influenced Greek religious concepts even more profoundly with regard to Poseidon and Zeus and the evolution of Poseidon from Mycenaean to Archaic times. The A. suggests that Poseidon corresponds to $\mathrm{El}$ and Zeus to Ba'al. Among the common features of Poseidon and El lies the association with the bull. D., however, does not attempt to explain Zeus' close connection to the bull. Towards the end of the chapter, he reconstructs a Mycenaean pantheon in which Poseidon occupies the role of father and king, while Zeus, his son, is a king of gods and men as well. Only after the fall of the Mycenaean palaces, the A. continues, did new social and political circumstances require a model of patrilineal brutal succession based on replacement rather than co-existence. It was at this time that Zeus and Poseidon became brothers and Kronos was introduced as their father. In the course of this decline, Poseidon also lost his position as the father of Erichthonios in the Attic pantheon.

10 In the conclusion (p.333-339), the A. offers a very brief summary of his main arguments. The bibliography, though generally well informed, reveals some puzzling omissions. For example, though Chapter Five, the longest in the book, deals with the structure and use of the Pylian land, the A. does not refer to E. Stavrianopoulou's highly relevant monograph. ${ }^{3}$ Even more baffling is the complete omission of the works of two most prominent historians of Greek religion, H.S Versnel and J.N. Bremmer.

11 Methodologically, D. reveals a strong tendency to use ancient myths as relics of historical incidents and religious developments uncritically, and more importantly to 
build assumptions upon assumptions upon speculations: Poseidon was certainly a very important deity in Mycenaean Pylos, but was he the most important one? Even if he was, what does this tell us about the panthea in Mycenae, Attica, Thebes, or Thessaly? D.'s undifferentiated use of mythological texts with little or no reference to ritual acts from the Archaic period in conjunction with dry administrative documents that deal with the practicalities of Mycenaean cult - as if the two categories of written sources were of the same class - poses a further methodological problem. In addition, the scrutiny that $\mathrm{D}$. dedicates to the Mycenaean material is missing in the chapters where he attempts to demonstrate the Ugaritic influence on the Greek/Mycenaean panthea, leading to an imbalance in the use and evaluation of materials. Furthermore, the A. does not really address the five centuries between the Mycenaean and the Archaic periods and their cultural, political, and religious significance to the questions he wishes to raise. The origins of the book in a project much broader and more ambitious are unfortunately far too obvious, so that one gets the impression that only some chapters of a larger manuscript have been brought together without being organically interwoven.

\section{NOTES}

1. On the fourth-century Apulian volute crater (Naples, Museo Nazionale H 1767), one can even see Perseus running away with Medusa's head.

2. The A. far too optimistically accepts the identification of the pre-Hellenic goddess Da with a water deity and ignores C. Trümpy's illuminating hypothesis, according to which Da should be identified with Potnia, see C.TRÜMPY, "Die Thesmophoria, Brimo, Deo und das Anaktoron: Beobachtungen zur Vorgeschichte des Demeterkultes," Kernos 17 (2004), p. 22-30.

3. E. StAVRIANopoulou, Untersuchungen zur Struktur des Reiches von Pylos, Partille, 1989.

\section{AUTHORS}

JOANNIS MYLONOPOULOS

Columbia University - New York 